\title{
ПРОБЛЕМА ШКІДЛИВИХ ЗВИЧОК У ПІДЛІТКІВ
}

\author{
О. І. Зарудна, Д. О. Зарудна, О. П. Абухажар, М. І. Караневич, Л. Л. Легка \\ ДвнЗ «Тернопільський державний медичний університет \\ імені І. Я. Горбачевського МОЗ Украӥни” \\ ННІ медсестринства
}

\begin{abstract}
У статті наведено дані анкетування підлітків щодо поширеності шкідливих звичок у їхньому середовищі, ставлення до шкідливих звичок школярів та їхнього оточення. Проведено аналіз отриманих результатів.
\end{abstract}

\section{THE PROBLEM OF BAD HABITS AMONG TEENAGERS}

\section{O. I. Zarudna, D. O. Zarudna, O. P. Abukhazhar, M. I. Karanevich, L. L. Lehka}

\section{Horbachevsky Ternopil State Medical University}

The article contains results of questionnaire among teenagers about bad habits, their own attitude to this problem, and views of surrounding people. The analysis of gained results is provided.

Вступ. Що таке шкідливі звички? Wikipedia стверджує, що це ряд звичок, які є шкідливими для організму людини. За даними цього ж таки поважного інтернет-видання, вони перешкоджають людині розвиватися як розумово, так і фізично. Серед цих звичок виділяють декілька найшкідливіших - це наркоманія, алкоголізм, токсикоманія та тютюнокуріння.

За результатами дослідження «Європейське опитування учнівської молоді щодо вживання алкоголю та наркотиків» (ESPAD), яке оприлюднило MO3, що тривало протягом 1995-2011 рр., та, крім України, проходило у 36 країнах Європи (в Україні дослідження проведено Українським інститутом соціальних досліджень імені Олександра Яременка за підтримки ЮНІСЕФ в Україні, у рамках відповідного міжнародного проекту) $[2,3]$ :

- досвід куріння мали 74 \% хлопців та 61 \% дівчат. Кожний шостий хлопець та кожна чотирнадцята дівчина за останні 30 днів викурювали більше шести цигарок на день;

- вперше спробували куріння у віці до 13 років 36 \% учнівської молоді (47 \% хлопців та $27 \%$ дівчат). $15 \%$ хлопців та 8 \% дівчат почали курити щоденно ще до досягнення 15 років;

- однією із найвагоміших причин поширеності тютюнокуріння $є$ доступність цигарок: 51 \% хлопців та 44 \% дівчат вважають, що зможуть легко дістати цигарки у разі потреби.
Тютюнокуріння призводить до негативних наслідків зі сторони центральної, дихальної та серцево-судинної проблеми підлітка.

щодо вживання алкоголю підлітками звернемося знову до результатів дослідження $\operatorname{ESPAD}[2,3]$. Так, за результатами опитування, кількість молодих людей віком 15-17 років, які вживали алкогольні напої хоча 6 раз у житті, сягає $87 \%$. Стан сп'яніння за останні 12 місяців відчували $40 \%$ учнів.

Крім того, зросла й популярність слабоалкогольних напоїв: 32 \% підлітків 15-17 років вживали їх під час останньої випивки у 2011 р. Дівчата більше вживають шампанське, слабоалкогольні напої та вино, а хлопці виявилися прихильниками пива та міцних алкогольних напоїв. Результати дослідження також свідчать, що істотно зросло вживання чистого алкоголю.

10 \% підлітків повідомили, що внаслідок вживання алкоголю з ними стався нещасний випадок або травма (7 \% у 2007 р.), а 8 \% (11\% серед хлопців та $6 \%$ серед дівчат) вказали на незахищені статеві контакти (3 \% у 2007 р.).

За умови вживання алкоголюу підлітків дуже швидко відбувається психічна деградація. Їхній інтелектуальний розвиток не відповідає віку, вони нездатні концентрувати увагу, засвоювати новий матеріал, страждають від порушення пам'яті, стають апатичними, до всього байдужими, крім випивки.

(ㄱ О. І. Зарудна, Д. О. Зарудна, О. П. Абухажар, М. І. Караневич, Л. Л. Легка, 2018 
Щодо вживання наркотиків підлітками статистичні дані можна знайти у соціологічному опитуванні 5 хвилі у межах проекту ESPAD, що було проведено серед 7512 учнів/студентів (3355 хлопців і 4157 дівчат) віком 15-17 років сільських та міських загальноосвітніх середніх шкіл, професійно-технічних та вищих навчальних закладів I-II та II-IV рівнів акредитації $[2,3]$. Воно виявило, що:

- 25 \% серед учнівської молоді мають досвід вживання заборонених наркотичних речовин;

- найбільш вживаними наркотиками залишаються марихуана і гашиш: 12 \% учнівської молоді вживали марихуану хоча 6 один раз;

- 3 \% опитаних вживали екстазі та мали досвід вживання «курильних» сумішей;

- вперше марихуану або гашиш пробують у 13 років (2 \%) або раніше, а $5 \%$ - у 15 років;

- важливо, що 11 \% підлітків вважають, що можна легко дістати марихуану або гашиш (серед хлопців $15 \%$, серед дівчат - $8 \%$ );

- 16 \% хлопців та 12 \% дівчат повідомили про те, що 1-2 рази мали можливість спробувати марихуану або гашиш, але не скористалися нею (у 2007 р. таких було $34 \%$ серед хлопців та $23 \%$ - серед дівчат);

- дослідження виявило, що основними місцями, де можна придбати марихуану та гашиш, $є$ дискотеки та бари, на другому місці - «точки» на вулиці або в парках, на третьому місці - вдома у торговців наркотиками, на четвертому - замовити через Інтернет, на п'ятому - навчальний заклад.

Вживання наркотиків губить не тільки тіло людини, але і її душу. Серед усіх медичних наслідків наркотичної залежності виділяють типові зміни особистості людей, які регулярно вживають психоактивні речовини. Це - збіднення і ослаблення психіки, втрата емоцій та інтересів, зменшення життєвого потенціалу.

Зважаючи на вже оприлюднені дані багатьох соціологічних опитувань, алкоголь, тютюн та наркотики $\epsilon$ доволі доступними для підлітків та становлять реальну загрозу для суспільства в цілому. Тому визначення поширеності шкідливих звичок, вивчення ставлення до них учнів та їхнього оточення слід розглядати як можливість подальшого впливу на свідомість молоді та їх подальший вибір.

Мета дослідження: на основі опитувальників вивчити поширеність, знання та ставлення підлітків до шкідливих звичок.

Основна частина. Для дослідження поширеності шкідливих звичок серед школярів старших класів загальноосвітніх шкіл віком 13-17 років, вивчення їхнього ставлення до шкідливих звичок та розуміння наслідків такої поведінки, було використано анонімне анкетування за допомогою стандартних анкет, рекомендованих шкільним психологом, та доповнених деякими уточнювальними запитаннями авторів дослідження [1]. Анкетування проводили на добровільних засадах.

У дослідженні взяли участь 30 учнів старших класів (10 хлопців та 20 дівчат). Середній вік опитаних хлопців - 14,8 року (від 13 до 17 років). Середній вік опитаних дівчат - 14,9 року (від 13 до 16 років).

Ствердну відповідь на запитання «Ти куриш?» дали 5 дівчат, один хлопець, а 2 дівчат та 2 хлопців вказали, що курять інколи або рідко. Одна дівчина 15 років відповіла, що уже поборола цю негативну звичку. 12 учнів користуються електронними сигаретами, 3 них 50 \% поєднують це з курінням звичайних цигарок (рис. 1).

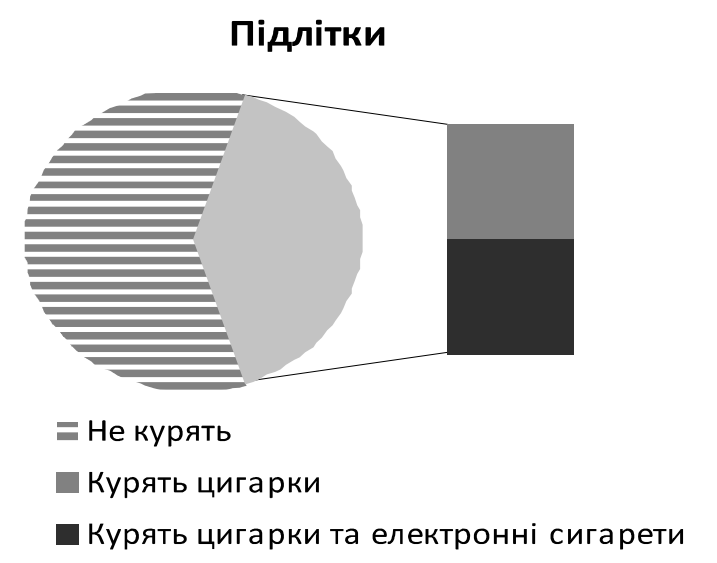

Рис. 1. Розподіл підлітків за ознакою куріння.

Вперше спробували курити в середньому у віці 12-13 років, одна дитина вказала, що вперше спробувала в 6-річному віці. Серед обставин: перебування в літньому таборі з друзями, під час святкування Нового року, дня народження тощо. Жоден не відповів, що спробував курити на самоті. При цьому 50 \% відповіли, що родичі та знайомі курять в їхній присутності (рис. 2).

Одночасно позитивне ставлення до курців має лише один учень, 20 учасникам опитування байдуже та 9 ставляться до оточуючих, які курять, негативно. Серед негативних наслідків куріння діти вказали лише на поганий вплив на бронхолегеневу систему, підвищений ризик розвитку раку та туберкульозу легень. 9 опитаних навпроти цього питання залишили пусте місце. Очевидно, що цих знань про шкоду куріння $є$ недостатньо. 


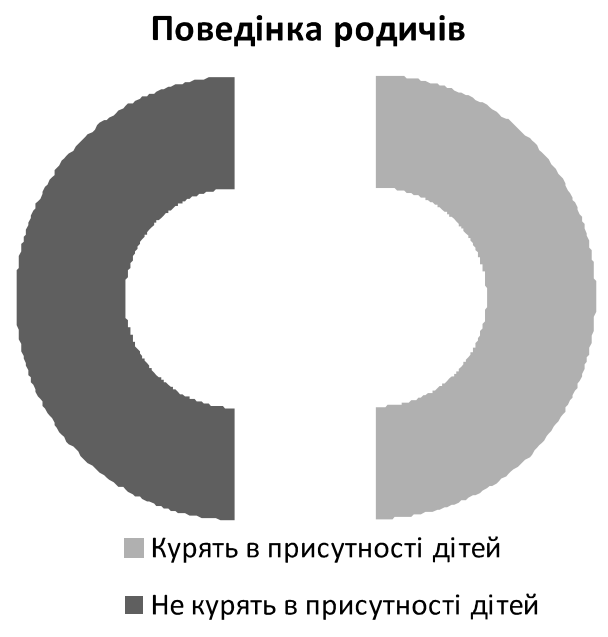

Puс. 2. Поведінка родичів у присутності дітей.

Відповідь на запитання: «Чи вживаєте ви алкоголь?» - негативна була отримана лише одна від особи жіночої статі 16 років, що складає лише 3,33 \% від усіх опитаних. А отже, 29 учасників експерименту (96,67 \%) - учнів старших класів у тій чи іншій мірі мали досвід вживання алкоголю (рис. 3).

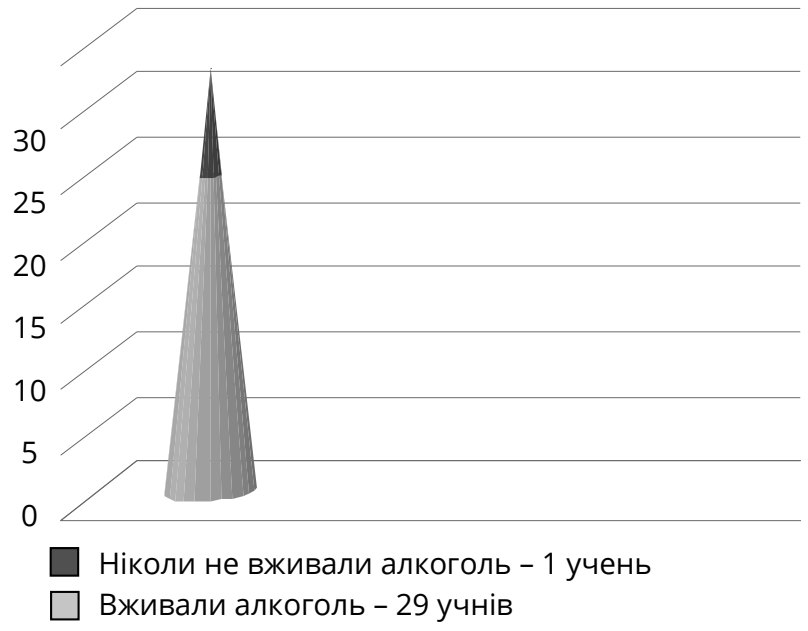

\section{Рис. 3. Розподіл опитаних за ознакою} вживання алкоголю.

11 дівчат та 3 хлопців відповіли, що вони вживають алкоголь, а 14 чоловік (8 дівчат та 6 хлопців) відповіли, що рідко. 5 учнів стверджують, що вживають алкоголь щомісяця, 4 - щотижня, інші - лише на свята. Учні, які вживають алкоголь, дали також ствердну відповідь на питання про вживання алкоголю оточуючими. Більшість спробувала алкоголь у віці 10-12 років на святкування дня народження чи родинних урочистостей. Цікавим є ставлення учнів до тих, хто вживає алкоголь. А саме: лише 2 учнів ставляться негативно до оточуючих, які вживають алкоголь, байдуже ставлення відзначили - 22 хлопців та дівчат, а 6 виявили позитивне ставлення до тих, хто вживає алкоголь (рис. 4).

\section{Ставлення до вживання алкоголю}

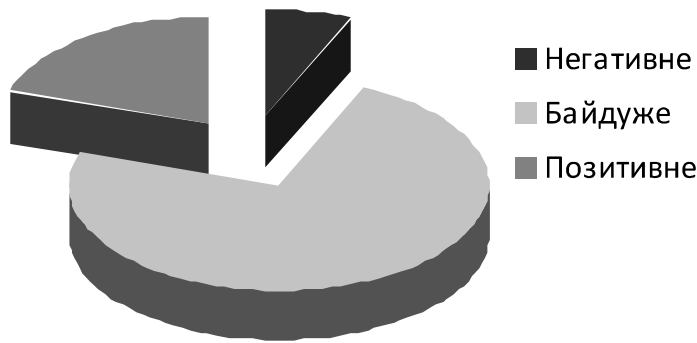

Рис. 4. Ставлення підлітків до вживання алкоголю оточуючими.

При цьому 17 опитаних (що більше від половини) вважають за нормальне явище вживання алкоголю в суспільстві, і лише 13 учнів вважають це явище негативним. На запитання, чи знають діти про ставлення їхніх батьків до тих, хто вживає алкоголь, виявилось, що один учень не знає ставлення своїх батьків до цього явища, 50 \% (15 учнів) - стверджують про негативне ставлення своїх батьків до питущих людей, а 14 дітей відповіли про байдуже ставлення їхніх родичів до цього явища (рис. 5).

\section{Ставлення батьків підлітків до питущих людей}
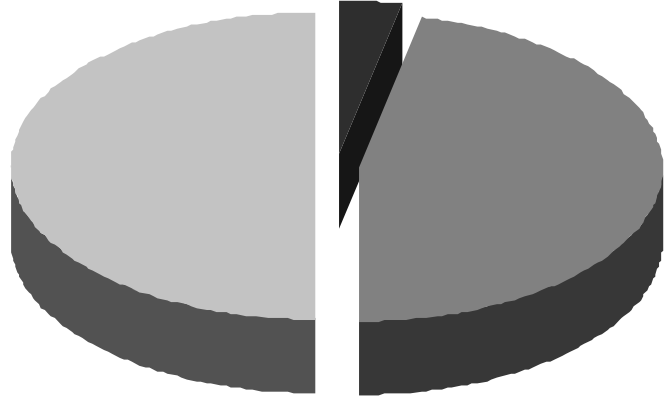

- Невідоме Байдуже Негативне

Рис. 5. Поінформованість дітей про ставлення їхніх батьків до питущих людей.

Знання учнів про шкідливий вплив алкоголю обмежується відомостями про токсичний вплив на печінку та погіршення пам'яті в питущих людей. Одночасно 6 учнів (3 дівчат та 3 хлопців) взагалі відповіли, що не знають про негативні сторони вживання алкоголю.

Щодо вживання наркотиків, то отримано лише одну позитивну відповідь від 16-річного учня (рис. 6). Отримані результати цілком протилежні до досвіду з алкоголем.

Вживання наркотичного засобу в підлітка викликало ейфорію. Йому відомо, що наркотики негативно впливають на головний мозок людини, негативно ставиться до тих, хто регулярно вживає наркотики, вважає, що це ненормально. Проте усе викладене не вберегло його від першої спроби в оточенні друзів. 


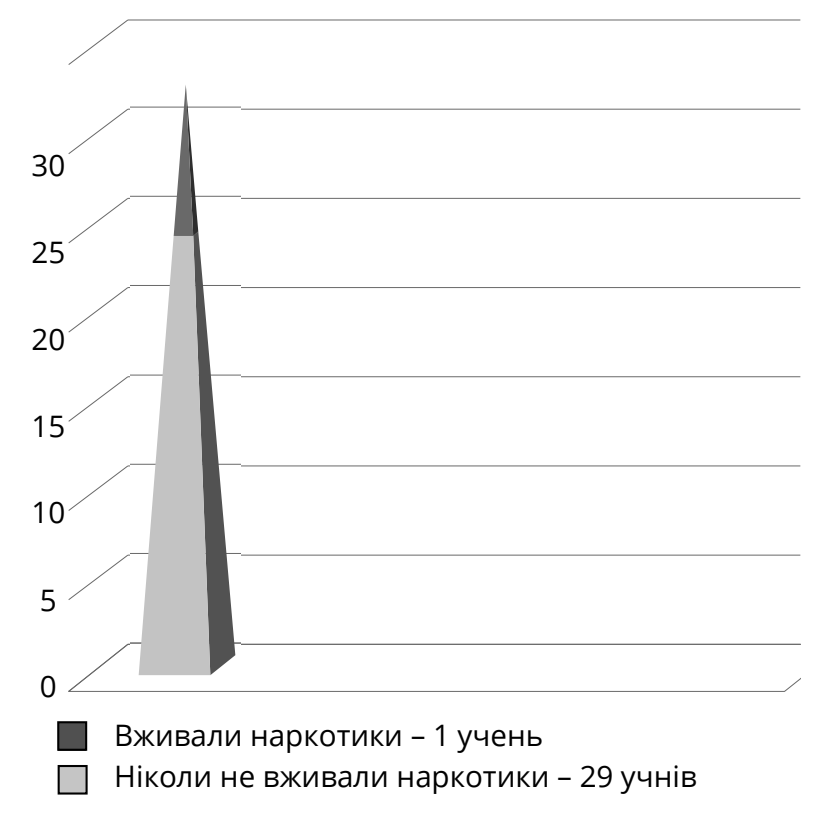

Рис. 6. Вживання наркотиків серед учнів.

Природно, що інші учні, які не пробували вживати наркотики, не змогли описати особисті відчуття з цього приводу. Однак 5 відповіли, що у їхньому оточенні $\epsilon$ люди, які вживають наркотики. 24 учнів стверджують про своє негативне ставлення до наркоманів, а 6 - байдуже (рис. 7).

Одночасно всі відповіли, що вживання наркотиків це ненормальне явище. А причиною початку вживання наркотичних речовин більшість вважає проблеми у житті, відчуття безвиході та вплив оточення.

Висновки. 1. 33,33 \% учнів (10 осіб як хлопці, так і дівчата) мають досвід куріння цигарок, а $40 \%$ (12 осіб) - електронних цигарок. 3 них 20 \% (6 хлопців) поєднують куріння традиційних цигарок та використання електронних сигарет. Серед сприяючих курінню факторів слід назвати куріння родичів та близьких в оточенні дітей, вплив друзів (жоден не вказав, що пробував курити на самоті), а також недостатню обізнаність з негативними наслідками куріння на організм людини.

2. 96,67 \% учнів старших класів мають досвід вживання алкоголю. Перший досвід вживання алкоголю спостерігають переважно у віці 10-12 років. При цьому стійке негативне ставлення до вживання алкоголю сформувалось лише у 20 \% учнів (6 опитаних), що ймо-

\section{СПИСОК ЛІТЕРАТУРИ}

1. Фіцула М. М. Методичні рекомендації з питань інформаційного забезпечення виховного процесу (зразки анкет) / М. М.Фіцула. - Тернопіль. - 1989. - 34 с.

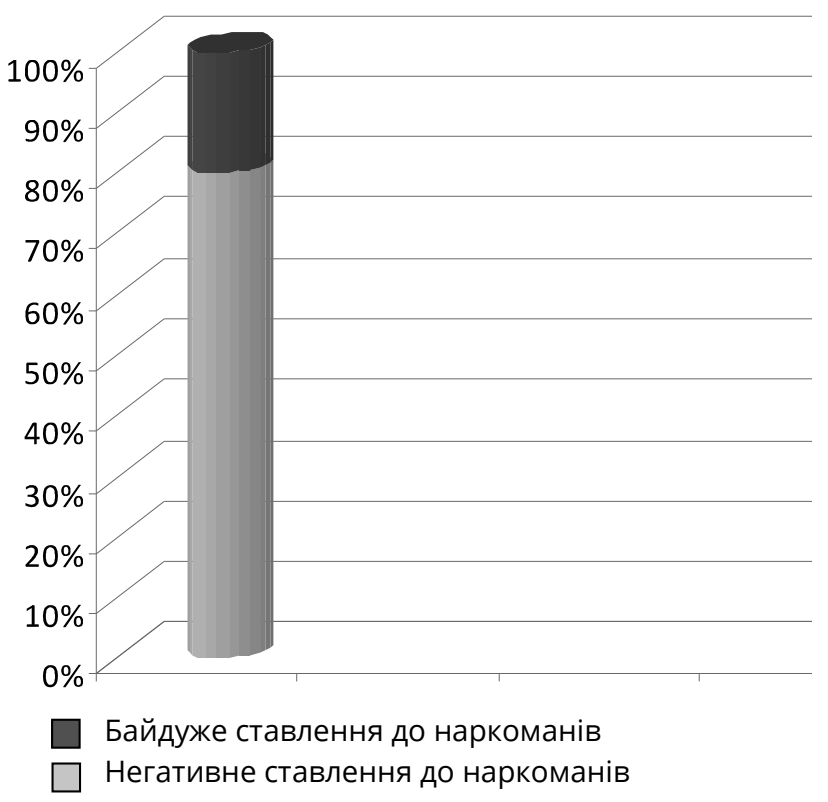

РUс. 7. Ставлення підлітків до наркоманів.

вірно, пов'язано з вживанням алкоголю в присутності дітей їхніми родичами та близькими.

3. Дуже обнадійливими є результати опитування щодо вживання наркотиків та ставлення до них. Лише один учень (3,33 \%) дав ствердну відповідь на це запитання. Інші учні не намагались спробувати вживання наркотиків. У 80 \% сформувалось негативне ставлення до вживання наркотиків, проте у 20 \% має місце байдуже ставлення, що можна пов'язати з недостатньою обізнаністю учнів про негативні наслідки наркоманії згідно з анкетуванням.

4. Враховуючи вищевикладене, слід вважати недостатніми заходи, що здійснюються на рівні держави (а саме: заборону реклами алкоголю та цигарок, пропаганду здорового способу життя у засобах масової інформації, застереження про негативні наслідки на пляшках з алкоголем та коробках цигарок). Дуже важливим є власний приклад найближчого оточення дитини, ії батьків, родичів, вчителів, близьких тощо. Посилити стійкість до шкідливих та небезпечних звичок серед учнів можна також за допомогою поглиблення їхніх знань про негативні наслідки зусиллями шкільної медичної сестри, вчителів, запрошених лекторів, батьків, приведенням наглядних прикладів, бесідами 3 людьми, які пережили негативний досвід зловживання.

2. Хухліна О. С. Тютюнопаління та його шкідливі наслідки / О. С. Хухліна, І. В. Дудка // Дайджест БДМУ. - 2017. - С. 9-12. 3. URL : http://www.espad.org. 